of the Forestry Commission; and private forestry in Scotland, by Sir John Milne Home.

The first article recalls how the original president of the Society was James. Brown, at that time deputy surveyor of the Forest of Dean and provisional head forester of Armiston, who is chiefly known as the author of "The Forester", the stendard book on forestry at that period. The Society was formed by a strong committee of nineteen which framed its constitution and its by-laws, subscriptions and so forth. Members were soon forthcoming, and the first Transactions of the Scottish Arboricultural Society, as it was then called, appeared four years later. During the past century the Society was constantly pressing the claims of forestry in Scotland on the Government, and committees and commissions were appointed by the House of Commons, without, however, much practical result until the present century.

In Sir Henry Beresford Pierce's well-informed article he points out that it was the Society (and, in particular, Munro Fergusson, afterwards Lord Novar, Sir John Sterling Maxwell and Lord Lovat) which pressed the Government to form a model State forest to be a pilot scheme to a much larger proposal that the Society put forward, namely, the afforestation of between three and four million acres in Scotland. As a practical outcome of this suggestion, the Royal Commission on Coast Erosion in 1909 proposed alternative schemes for the afforestation of nine million or six million acres in the United Kingdom. It was the First World War which eventually brought these ultimative schemes to a head in the Acland Report and the Government Bill forming the Forestry Commission at the close of the War.

The Society may be congratulated on the proposed centenary volume, for in that should be assembled the true forestry history of the period and the ideas which make for an appreciation of what forests and forestry really imply to a country and its people.

E. P. Stebbing

\section{ADAPTIVE CHANGES IN SUNFLOWER}

G E. BLACKMAN AND G. L. WILSON have . continued their physiological and ecological analyses of plant environment by investigating the adaptive changes in the vegetative growth and development of Helianthus annuus as induced by alterations in light-level (Ann. Bot., 18, No. 69, 71 ; 1954). To this end pot experiments were carried out in which sunflowers in the early vegetative phase were first grown for a period under three levels of light $(1 \cdot 0,0 \cdot 5$ and $0 \cdot 24$ daylight). Afterwards, pots from each light-group were subdivided into three so that in a second period plants could be subjected to the nine possible combinations of the same three light-intensities before and after transference. During the post-transference period of adaptation to either a higher or a lower intensity the net assimilation-rate was found to be logarithmically proportional to the light received and there was no residual effect of the initial light treatments. Eight days after transference the leaf-area ratios (total leaf area/total plant weight) at each light-level became adjusted to a new equilibrium irrespective of the large initial differences in the ratio induced by the pre-transference intensities. In both periods there was an inverse and logarithmic relationship between the leaf-area ratio and falling light-intensity; consequently, the greater the degree of shading in the pre-transference period, the higher were the mean ratios in the second period. Since the relative growth-rate is the product of the net assimilation-rate and the leaf-area ratio, the variations in the leaf-area ratio in the post-transference period induced by the initial light treatments were reflected in the relative growth-rates. Thus plants. transferred from a lower to a higher light-intensity were leafier and initially grew faster than plants maintained at the higher level in both periods: the converse conditions led to a reduction in the growthrate.

It was observed that shading depresses the growth of the roots, but that the relative growth-rate is dependent on the light-intensity in both the pretransference and post-transference periods. The growth-rate was maximal when plants were moved from the lowest to the highest intensity.

In terms of leaf weight, decreasing the lightintensity decreased the relative growth-rate and there was no consistent after-effect of the initial light treatments. The rate of expansion in leaf area tends to be highest at the intermediate level of 0.5 daylight, and over all the post-transference intensities the rates were maximal for those plants which received initially full daylight. The ratio of leaf area to leaf weight was inversely and logarithmically proportional to the light-level. After transference, the slopes of the regressions were independent of the initial light treatments; but the mean ratios were inversely correlated with the initial degree of shading. These observations are discussed with particular reference to the control of growth exerted by growthregulating substances: on the basis of existing knowledge, no adequate interpretation of the adaptive changes yet seems possible.

\section{DISTRIBUTION OF LAMINARIACEAE AROUND SCOTLAND}

\author{
By F. T. WALKER
}

Institute of Seaweed Research, Musselburgh, Midlothian

TIFTY-NINE detailed surveys, covering 80,000 acres of the sub-littoral zone off the north-east, south-east and south-west mainland of Scotland, the Isle of Skye and several of the islands of Orkney, have been completed by the Botanical Division of the Institute of Seaweed Research.

The detailed surveys were preceded by aerial photogrammetric surveys. They were carried out at all times of the year and during seven years, 1946-53, and so include seasonal and cyclic changes. They covered areas of the sea-bed from low-water mark down to ten fathoms $(19 \mathrm{~m}$.), where the dominant species was either Laminaria cloustoni, L. digitata or $L$. saccharina. (Some surveys were restricted to depths of 1-6 fathoms.) Tidal streams ranged from 0 to $7 \mathrm{knots}$ and tides from low-water mark to 3 fathoms $(6 \mathrm{~m}$.) according to time and location.

In the course of the fifty-nine surveys, operated from motor-vessels, some 50,000 quadrats were taken from the sea-bed by means of calibrated spring-grabs which close by trigger action on reaching the bottom ${ }^{1}$.

The 1946-49 surveys employed methods of quadrat sampling along transects measured'by range-finder, 